MAPS SHOWING NATURAL AGGREGATES OF THE

CONTERMINOUS UNITED STATES

BY William H. Langer and Donna L. Belval

U.S. Geological Survey

OPEN-FILE REPORT 83-743

This report is preliminary and has not been reviewed for conformity with U.S. Geological survey editorial standards. 


\section{General References}

General references were consulted in preparing the data for most of the nation; these are listed below, and will not be repeated under each individual state listing:

Davies, W. E., Simpson, J. H., Ohlmacher, G. C., Kirk, W. S., and Newton, E. G. 1977, Map showing engineering aspects of karst in the United States: U.S. Geological Survey Open-File Report 76-623, scale $1: 7,500,000$.

French, A. E., 1967, Mineral raw materials for construction: U.S. Geological Survey National Atlas, p. 182-183, scale $1: 7,500,000$.

Hubbard, H. A., and Ericksen, G. E., 1973, Limestone and dolomite, in Brobst, D. A., and Pratt, W. P., eds., United States mineral resources: U.S. Geoloqical Survey Professional Paper 820, p. 357-364.

Hunt, C. B., 1977, Surficial geology of the United States: U.S. Geological Survey Open-File Report 77-232, scale $1: 7,500,000$.

King, P. B., and Beikman, H. M., 1974, Geologic map of the United States: U.S. Geological Survey, scale 1:2,500,000. 
Regional references were consulted in delineating the limits of Region I or the distribution of glacial deposits on plate 1; these are listed below and will not be repeated under each individual state listing:

Crandell, D. R., 1965, The glacial history of western Washington and Oregon, in Wright, H. E., Jr., and Frey, D. G., eds., The Quaternary of the United States: Princeton, New Jersey, Princeton University Press, p. 341-345.

Geological Society of America, 1959, Glacial map of the United States east of the Rocky Mountains: compiled and edited by a committee of the Division of Earth Sciences, National Research Council, scale $1: 1,750,000$ Richmond, G. M., 1965, Glaciation of the Rocky Mountains in Wright, H. E., Jr., and Frey, D. G., eds., The Quaternary of the United States: Princeton, New Jersey, Princeton University Press, p. 217-230.

Richmond, G. M., Fryxell, Roald, Neff, G. E., and Weis, P. L., 1965, The Cordilleran Ice Sheet of the northern Rocky Mountains and related Quaternary history of the Columbia Plateau, in Wright, H. E., Jr., and Frey, D. G., eds., The Quaternary of the United States: Princeton, New Jersey, Princeton University Press, p. 231-242. Wahrhaftig, Clyde, and Birman, J. H., 1965, The Quaternary of the Pacific Mountain systems in California, in Wright, H. E., Jr., and Frey, D. G., eds., The Quaternary of the United States: Princeton University Press, p. 299-340. 
The references that were consulted in delineating the offshore sand and gravel deposits on plate 1 are listed below and will not be repeated under each individual state listing:

Hollister, C. D., 1973, Atlantic continental shelf and slope of the United States--texture of surface sediments from New Jersey to southern Florida: U.S. Geological Survey Professional Paper 529-M, p. M1-M23. Moore, G. W., and Luken, M. D., 1979, Offshore sand and gravel resources of the Pacific Northwest: Oregon Geology, Oregon Department of Geology and Mineral Industries, v. 4I, no.9, p. 143-151.

Schlee, John, and Pratt, R. M., 1970, Atlantic continental shelf and slope of the United States--gravels of the northeastern part: U.S. Geological Survey Professional Paper 529-H, p. $\mathrm{H} 1-\mathrm{H} 39$.

Venkatarathnam, K., and McManus, D. A., 1973, Origin and distribution of sands and gravels on the northern continental shelf of Washington: Journal of Sedimentary Petrology, v. 43, no. 3, p. 799-811.

Welday, E. E., and Williams, J. W., 1975, Offshore geology of California: State of California Department of Conservation, scale $1: 500,000$. 
This section lists by State, the sources of data used in compiling plates 1 and 2 . In addition, plates 1 and 2 were sent to the state geological surveys and highway departments, requesting their review and comments. The symbol * or + before a State name indicates that the state geological survey or highway department, respectively, responded to this request. The comments of the State agencies are greatly appreciated; however, their comments do not necessarily represent an endorsement of these maps. Furthermore the state agencies responding neither officially approved the maps nor do they have any official responsiblity for the data shown on the maps.

\section{* Alabama}

Murphy, T. D., 1960, Distribution of silica resources in eastern United States: U.S. Geological Survey Bulletin 1072-L, p. 657-665.

Szabo, M. W., 1967, Sand and gravel in Alabama, a summary report: Geological Survey of Alabama, Division of Economic Geology, $41 \mathrm{p}$.

$$
\text { * Arizona }
$$

Baker, Simon, and McCleneghan, T. J., eds., 1966, An Arizona economic and historic atlas: University of Arizona, Tucson, and the Valley National Bank, Phoenix, $40 \mathrm{p}$.

Keith, S. B., 1969, Sand and gravel, in Mineral and water resources in Arizona: U.S. Geological Survey, Arizona Bureau of Mines, and U.S. Bureau of Reclamation, p. 424-441. 
+ Arkansas

Branner, G. C., 1942, Mineral Resources of Arkansas: Arkansas Geological Survey Bulletin 6, $101 \mathrm{p}$.

Fisk, H. N., 1944, Geological investigation of the alluvial

valley of the lower Mississippi River: Vicksburg, Mississippi River Commission, Vicksburg, Mississippi, 78 p.

Haley, B. R., 1976, Geologic map of Arkansas: U.S. Geological Survey, scale 1:500,000.

$$
\text { * + California }
$$

Goldman, H. B., 1966, Sand and gravel, in Mineral and water resources of California: U.S. Geological Survey, California Division of Mines and Geology, and U.S. Bureau of Mines, p. $361-369$.

_-__ 1968, Sand and gravel in California, an inventory of deposits: California Division of Mines and Geology Bulletin 180 , Parts A, B, and C. Jennings, C. W., assisted by Strand, R. G., and Rogers, T. H., 1977, Geological map of California: California Division of Mines and Geology, scale 1:750,000.

+ Colorado

Schwochow, S. D., Shroba, R. R., and Wicklein, D. C., 1974, Sand, gravel, and quarry aggregate resources, Colorado Front Range counties: Geological survey of Colorado Special Publication 5-A, 43 p., map scale 1:250,000.

Tweto, Ogden, 1979, Geologic map of Colorado: Geological Survey of Colorado, scale $1: 500,000$. 


\section{Connecticut}

Only those sources listed under general references.

* Delaware

U.S. Geological Survey, 1964, Map showing surficial geology and extent of glaciation in the Delaware River basin and New Jersey: U.S. Geological Survey Professional Paper 381, plate 7 , scale 1:500,000.

* + Florida

Cook, C. W., 1945, Geologic map of Florida: Florida Geological Survey and U.S. Geological survey, approximate scale $1: 1,000,000$.

Murphy, T. D., 1960, Distribution of silica resources in eastern United States: U. S. Geological Survey Bulletin 1072-L, p. 657-665.

Scott, T. M., Hoenstine, R. W., Knapp, M. S., Land, Ed., Ogden, G. M., Jr., Deuerling, Richard, and Neel, H. E., 1980, The sand and gravel resources of Florida: Florida Bureau of Geology Report of Investigations no. 90.41 p. Schmidt, Walter, Hoenstine, R. W., Knapp, M. S., Land, Ed., Ogden, G. M., Jr., and Scott, T. M., 1979, The limestone, dolomite and coquina resources of Florida: Florida Bureau of Geology Report of Investigations no. 88,54 p. Vernon, R. O., and Puri, H. S., 1965, Florida geology: U.S. Geological Survey and Florida Board of Conservation Map Series no. 18, scale $1: 2,000,000$. 


$$
\text { * + Georgia }
$$

Erickson, G. E., and Cox, D. P., 1968, Limestone and dolomite, in Mineral resources of the Appalachian Region: U. S. Geological Survey Professional Paper 580. p. 163-167. Maxwell, C. H., Frendzel, D. J., and Stansfield, R. G., 1968, Sand and gravel, in Mineral resources in the Appalachian Region: U.S. Geological Survey Professional Paper 580, p. 254-261.

Teas, L. P., 1921, Preliminary report on the sand and gravel deposits of Georgia: Georgia Geological Survey Bulletin 37, 392 p.

\section{Idaho}

Only those sources listed under general references.

$$
\text { * + Illinois }
$$

Illinois State Geological Survey, undated (received 1976), Sand and gravel resources of Illinois: scale $1: 1,000,000$. Lineback, J. A., 1979, Quaternary deposits of Illinois: Illinois State Geological Survey, scale 1:500,000.

$$
\text { * + Indiana }
$$

Indiana Geological Survey, 1979, Map of Indiana showing unconsolidated deposits: Indiana Geological Survey Miscellaneous Map 26, no scale. Wayne, W. J., 1960, Map of Indiana showing glacial deposits: Indiana Geological Survey Report of Progress 17, plate 1, scale $1: 1,000,000$. 


$$
\text { * Iowa }
$$

Iowa Geological Survey, 1969, Bedrock of Iowa: Iowa Geological survey, no scale.

_-_ 1976, Quaternary terrain and materials in Iowa:

Iowa Geological Survey, no scale.

$$
\text { * }+ \text { Kansas }
$$

Kulstad, R. O., and Nixon, E. K., 1951, Kansas pits and quarries: State Geological Survey of Kansas Bulletin 90, Part 1. State Geological Survey of Kansas, 1964, Geologic map of Kansas: University of Kansas and state Geological Sual Survey of Kansas, scale $1: 500,000$.

$$
\text { * + Kentucky }
$$

Erickson, G. E., and Cox, D. P., 1968, Limestone and Dolomite, in Mineral resources of the Appalachian region: U.S. Geological Survey Professional Paper 580, p. 163-167. Johnson, J.H., stapleton, J. M., and McGrain, Preston, compilers, 1962, Mineral resources and mineral industries of Kentucky: Kentucky Department of Commerce and Kentucky Geological Survey, scale 1:500,000. Maxwell, C. H., Frendzel, D. J., and Stansfield, R. G., 1968, Sand and gravel, in Mineral resources in the Appalachian region: U.S. Geological Survey Professional Paper 580, p. 254-261. 
McGrain, Preston, 1982a, Geology of construction materials in Kentucky, in Proceedings of the 18th forum on geology of industrial minerals: Indiana Geological Survey Occasional Paper 37 , in press. 1982b, Overview of sand and gravel resources of Kentucky: Kentucky Geological Survey Series XI, Report of Investigations 1 .

$$
\text { * + Louisiana }
$$

Fisk, H. N., 1944, Geoloical investigation of the alluvial valley of the lower Mississippi River: Vicksburg, Mississippi River Commission, Vicksburg, Mississippi, 78 p.

Woodward, T. P., and Gueno, A. J., Jr., 1941, Generalized map of Louisiana showing regions of gravel exposures, in The sand and gravel deposits of Louisiana: Louisiana Geological Survey, Bulletin no. 19, 429 p.

$$
\text { * + Maine }
$$

Only those sources listed under general references.

$$
\text { * Maryland }
$$

Ericksen, G. E., and Cox, D. P., 1968, Limestone and Dolomite, in Mineral resources of the Appalachian region: U.S. Geological Survey Professional Paper 580, p. 163-167.

Thompson, Derek, Murphy, C. E., Wiedel, J. W., Porter, F. W., III, Roswell, C. A., and Harper, R. A., 1977, Atlas of Maryland: University of Maryland, College Park, Maryland, 116 p. 
+ Massachusetts

only those sources listed under general references.

* + Michigan

Michigan Geological Survey, 1969, Limestone resources of Michigan: Michigan Geological Survey, no scale.

$$
\text { * + Minnesota }
$$

Schwartz, G. M., and Prokopovich, N. (adapted from F. Leverett), 1966, Main areas of sand and gravel (inset), Map of mineral resources of Minnesota: Minnesota Geological Survey, University of Minnesota, inset has no scale, resource map scale $1: 1,000,000$.

$$
\text { * + Mississippi }
$$

Bicker, A. R., Jr., 1970, Economic minerals of Mississippi: Mississippi Geological, Economic, and Topographic Survey Bulletin 112, 80 p.

Cross, R. D., ed., 1974, Sand, gravel, iron, and aluminum (map), Atlas of Mississippi: Jackson, Mississippi, University Press of Mississippi, 187 p.

$$
\text { * }+ \text { Missouri }
$$

Fisk, H. N., 1944, Geological investigation of the alluvial valley of the lower Mississippi River: Vicksburg, Mississippi River Commission, Vicksburg, Mississippi, $78 \mathrm{p}$.

Howe, W. B., 1980, Generalized geologic map of Missouri: Geology and Land survey, Missiouri Department of Natural Resources, no scale. 
Martin, J. A., 1967, Sand and gravel, in Mineral and water resources of Missouri: U.S. Geological Survey Missouri Division of Geological Survey and Water Resources, p. 196-203.

Missouri Geological Survey, 1979, Geologic map of Missouri: Missouri Geological Survey, scale 1:500,000. Wharton, H. M., Martin, J. A., Rueff, A. W., Robertson, C. E., Wells, J. S., and Kisvarsanyi, E. B., 1969, Missouri minerals--resources, production, and forecasts: Missouri Geological Survey and Water Resources special Publication no. $1,303 \mathrm{p}$.

$$
\text { * Montana }
$$

Larrabee, D. M., and Shride, A. F., compilers, 1946a, Preliminary map showing sand and gravel deposits of Montana: U.S. Geological Survey, Missouri Basin Studies 6, scale 1:500,000. Ross, C. P., Andrews, D. A., and Witkind, I. J., compilers, 1955, Geologic map of Montana: U.S. Geological Survey, scale $1: 500,000$.

\section{+ Nebraska}

Weeks, R. A., and Larrabee, D. M., compilers, 1948, Preliminary map showing sand and gravel deposits in Nebraska: U.S. Geological Survey Missouri Basin Studies No. 7, scale $1: 750,000$. 
+ Nevada

Olson, R. H., 1964, Sand and gravel, in Mineral and water

resources of Nevada: U. S. Geological Survey and Nevada Bureau of Mines, p. 240-243.

Tagg, K. M., and others, compilers, 1964, Geologic map of Nevada, in Mineral and water resources of Nevada: U. S. Geological Survey and Nevada Bureau of Mines, facing p. 12 .

* New Hampshire

Only those sources listed under general references.

* + New Jersey

U.S. Geological Survey, 1964, Map showing surficial geology and extent of glaciation in the Delaware River basin and New Jersey: U.S. Geological Survey Professional Paper 381, plate 7 , scale $1: 500,000$.

* + New Mexico

Austin, G. S., Kottlowski, F. E., and Siemers, W. T., 1982, Industrial minerals of New Mexico in 1981, in Austin, G. S., ed., Industrial rocks and minerals of the southwest: New Mexico Bureau of Mines and Mineral Resources Circular 182 , p. 9-16.

Carter, W. D., 1965, Sand and gravel, in Mineral and water resources of New Mexico: U.S. Geological Survey, New Mexico Bureau of Mines and Mineral Resources, and New Mexico Oil Conservation Committee, p. 353-358.

New Mexico State Highway Department, 1972, Geology and aggregate resources, District 2: New Mexico State Highway Department and U. S. Department of Transportation, $120 \mathrm{p}$. 


$$
\text { * + New York }
$$

Only those sources listed under general references.

* North Carolina

Murphy, T. D., 1960, Distribution of silica resources in eastern United States: U. S. Geological Survey Bulletin 1072-L, p. 657-665.

$$
\text { * + North Dakota }
$$

Bluemle, J. P., 1977, Geologic map of North Dakota: North Dakota Geological Survey Miscellaneous Series Map 19, scale $1: 1,000,000$

$$
\text { + Ohio }
$$

Goldthwait, R. P., White, G. W., and Forsyth, J. L., 1967, Glacial map of Ohio: U.S. Geological Survey Miscellaneous Investigations Series Map I-316, scale 1:500,000.

$$
\text { * + Oklahoma }
$$

Branson, C. C., and Johnson, K. K., 1972, Generalized geological map of Oklahoma, in Geology and earth resources of Oklahoma: Oklahoma Geological Survey, 8 p.

$$
\text { * + Oregon }
$$

Peck, D. L., 1961, Geologic Map of Oregon west of the 121st meridian: U.S. Geological Survey Miscellaneous Investigations Series Map I-325, scale 1:500,000.

Schlicker, H. G., 1969, Sand and gravel, in Mineral and water resources of Oregon: U.S. Geological Survey, Oregon Department of Geology and Mineral Industries, U.S. Bureau of Reclamation, Bonneville Power Administration and U. S. Bureau of Mines, p. 233-235. 
Walker, G. W., 1977, Geologic map of Oregon east of the 12lst meridian: U. S. Geological Survey Miscellaneous Investigations Series Map I-902, scale 1:500,000.

$$
\text { * + Pennslyvania }
$$

Maxwell, C. H., Frendzel, D. J., and Stansfield, R. G., 1968, Sand and gravel, in Mineral resources in the Appalachian region: U.S. Geological Survey Professional Paper 580, p. 254-261.

+ Rhode Island

only those sources listed under general references. * + South Carolina

Buie, B. F., 1949, Industrial minerals and rocks, in Shiver, H. E., Buie, B. F., and Eldredge, I. F., South Carolina raw materials: Columbia, South Carolina, University of South Carolina Press, p. 85-219. Murphy, T. D., 1960, Distribution of silica resources in eastern United States: U.S. Geological Survey Bulletin 1072-L, p. 657-665.

Smith, L. L., 1961, Economic mineral localities in South Carolina: University of South Carolina, scale 1:780,000. + South Dakota

Bruce, R. L., 1964, Sand and gravel, in Mineral and water resources of South Dakota: U.S. Geological Survey and South Dakota State Geological Survey p.93-96. 


\section{Tennessee}

Ericksen, G. E., and Cox, D. P., 1968, Limestone and Dolomite, in Mineral resources of the Applachian region:

U.S. Geological Survey Professional Paper 580, p. 163-167. Fisk, H. N., 1944, Geological investigation of the alluvial valley of the lower Mississippi River: Vicksburg, Mississippi River Commission, Vicksburg, Mississippi, 78, p. Hardeman, W. D., and Miller, R. A., 1959, Mineral resources and mineral industries of Tennessee: Tennessee Department of Conservation and Commerce, Division of Geology, scale $1: 500,000$.

Tennessee Valley Authority, 1970, Mineral resources of the Tennessee Valley region: scale 1:640,000.

$$
\text { * + Texas }
$$

Garner, L. E., St. Clair, A. E., and Evans, T. J., compilers, 1979, Mineral resources of Texas: University of Texas at Austin, Bureau of Economic Geology, scale $1: 1,000,000$. Kier, R. S., Garner, L. E., and Brown, L. F., Jr., 1977, Land resources of Texas: The university of Texas at Austin, Bureau of Economic Geology, scale 1:500,000.

$$
\text { * + Utah }
$$

Hintze, L. F., 1975, Geological highway map of Utah: Brigham Young University, Department of Geology, scale 1:1,000,000. Van Horn, Richard, 1964, Sand and gravel, in Mineral and water resources of Utah: U. S. Geological Survey, Utah Geological and Mineralogical Survey, and the Utah Water Power Board, p. 215-218. 
* + Vermont

Vermont Geological Survey, 1961, Centennial geologic map of

Vermont: Vermont Geological Survey, scale 1:250,000. Vermont Geological Survey, 1970, Surficial geologic map of

Vermont: Vermont Geological survey, scale 1:250,000. * + Virginia

Ericksen, G. E., and Cox, D. P., 1968, Limestone and dolomite, in U.S. Geological Survey and U.S. Bureau of Mines, Mineral resources of the Appalachian region: U.S. Geological Survey Professional Paper 580, p. 163-167. LeVan, D. C., and Harris, W. B., 1971, Mineral resources of Virginia: Virginia Department of Conservation and Economic Development, and Division of Mineral Resources, scale 1:500,000.

Pharr, R. F., and Calver, J. L., 1963, Mineral industries and resources of Virginia: Virginia Department of Conservation and Economic Resources, scale 1:500,000.

\section{* Washington}

Huntting, M. T., Bennett, W. A. G., Livingston, V. E., and Moen, W. S., compilers, 1961, Geologic map of Washington: Washington Department of Conservation and Division of Mines and Geology, scale $1: 500,000$.

Valentine, G. M., revised by Huntting, M. T., 1961, Map showing principal areas of sand and gravel, in Inventory of Washington minerals: Washington Division of Mines and Geology Bulletin 37 , part 1, v. 2, plate 34 . 


$$
\text { * + West Virginia }
$$

Cardwell, D. H., Erwin, R. B., and Woodward, H. P., compilers, 1968, Geologic map of Western Virginia: West Virginia Geological and Economic Survey, scale 1:250,000. Ericksen, G. E., and Cox, D. P., 1968, Limestone and Dolomite, in Mineral resources of the Appalachian region:

U.S. Geological Survey Professional Paper 580, p. 163-167. Maxwell, C. H., Frendzel, D. J., and Stansfield, R. G., 1968, Sand and gravel, in Mineral resources in the Appalachian region: U.S. Geological Survey Professional Paper 580, p. 254-261.

$$
\text { * }+ \text { Wisconsin }
$$

Dutton, C. E., 1976, Introduction, in Mineral and water resources of Wisconsin: U.S. Geological Survey, p. 1-8. Friz, T. O., 1975, Wisconsin glacial deposits (after Thwaites, 1956), in Mineral resources, mining, and land use planning in Wisconsin: Wisconsin Geological and Natural History Survey, $61 \mathrm{p}$. Hadley, D. W., 1976, Crushed stone, in Mineral and water resources of Wisconsin: U. S. Geological Survey, p. 74-79.

Wisconsin Geologic and Natural History Survey, 1971, Geologic map of Wisconsin: University of Wisconsin, Geologic and Natural History Survey, no scale. 


$$
\text { * + Wyoming }
$$

Eckel, E. B., 1959, A reconnaissance map of the sand and gravel deposits in Wyoming: U.S. Geological Survey Open-File Report, scale 1:500,000.

Larrabee, D. M., and Shride, A. F., compilers, 1946b, Preliminary map showing sand and gravel deposits of Wyoming: U. S. Geological Survey, Missouri Basin Studies no. 5, scale $1: 500,000$.

Love, J. D., Weitz, J. L., and Hose, R. K., 1955, Geologic map of Wyoming: U.S. Geological Survey, scale 1:500,000. 